\title{
Aspergillus favus Infection of Peanuts in Thailand
}

\author{
S. SaIto*1, S. KaWASUGI ${ }^{* 2}$, O. TSURUTA*1 and M. MANABE*1 \\ 斉藤 道彦*1, 川杉 正一*2, 鶴田 理*1, 真鍋 勝*1 \\ タイ産ピーナッツの Aspergillus flavus 污染
}

\begin{abstract}
Aspergillus flavus infection of agricultural commodities in tropical areas has received much attention because it may cause aflatoxin contamination. However, it has not yet been clear when the initial infection of peanuts by $A$. flavus takes place. For example, a paper ${ }^{1)}$ reported on the common occurrence of $A$. flavus in peanuts before harvest in India. However, the authors' investigation could not indicate that $A$. flavus infection may occur in the field before harvest ${ }^{2}$.

This paper deals with an examination of $A$. flavus infection of Thai peanuts at harvest time using some samples from different regions.
\end{abstract}

\section{Materials and Methods}

\section{Samples}

The peanuts samples used in this study were harvested in rainy season (September 1984). They were 7 varieties of peanuts from test fields (Nos. 1-2, 4 and 6-7) and farmer's fields (Nos. 3 and 5). One kernel sample (No. 8) sold in market was also examined.

*1 National Food Research Institute, Ministry of Agariculture, Forestry and Fisheries (21-2 Kannondai, Yatabe-machi, Tsukuba-gun, Ibaraki 305)

農林水産省食品総合研究所（テ305 茨城県筑波 郡谷田部町観音台2-1-2)

*2 Tropical Agriculture Research Center, Ministry of Agriculture, Forestry and Fisheries (1-2 Oowashi, Yatabe-machi, Tsukuba-gun, Ibaraki 305)

農林水産省熱帯農業研究センター（テ305 茨城 県筑波郡谷田部町大わし1-2)

\section{Examination of fungal infection}

After the pods of each sample were shelled, kernels and shells were surface-sterilized in $1 \%$ $\mathrm{NaOCl}$ solution and rinsed with water. Fifty kernels and 36 pieces of 1/4-shells of each sample were plated (six per plate) on PDA and M40Y agar in six partitioned Petri dishes and incubated for 7 to 10 days at $25 \mathrm{C}$.

3. Artificial inoculation test

In order to examine whether the tested kernels are resistant to $A$. flavus infection, artificial inoculation test was carried out. The kernels of each sample previously confirmed to be free from $A$. flavus by plating test on agar media were inoculated individually by a loop of conidia suspension of $A$. flavus and incubated at $25 \mathrm{C}$.

\section{Results and Discussion}

The results of examination of fungal infection for kernels and shells are summarized in Table 1 and Fig. 1 respectively. These results show that A. flavus infection was not detected in both kernels and shells of Nos. 1 to 7 samples. On the contrary, the marketed kernel sample (No. 8) yielded A. flavus infection with high frequency. Thus, natural infection was detected only from the marketed kernels. From these results, it is suggested that $A$. falvus infection of peanuts mainly occurs in marketing channels (during from harvesting and handling to storage). In fact, the artificial inoculation test revealed that $A$. flavus could invade easily into all of tested kernels.

There was a tendency that Macrophoma sp. 
Table 1. Mycoflora of peanut kernels harvested in rainy season (September 1984)

\begin{tabular}{|c|c|c|c|c|c|c|c|c|c|c|c|c|c|c|c|c|}
\hline \multirow[b]{2}{*}{ Fungus } & \multicolumn{16}{|c|}{ Percentage of infected kernels } \\
\hline & \multicolumn{2}{|c|}{$\begin{array}{c}(1) \\
\text { PDA M40Y }\end{array}$} & $\begin{array}{r}(2) \\
\text { PDA }\end{array}$ & M40Y & \multicolumn{2}{|c|}{$\begin{array}{c}(8) \\
\text { PDA M40Y }\end{array}$} & \multicolumn{2}{|c|}{$\begin{array}{c}(4) \\
\text { PDA }\end{array}$} & \multicolumn{2}{|c|}{$\begin{array}{c}(\varpi) \\
\text { PDA } \\
\end{array}$} & \multicolumn{2}{|c|}{$\begin{array}{c}(6) \\
\text { PDA }\end{array}$} & \multicolumn{2}{|c|}{$\begin{array}{c}(7) \\
\text { PDA } \mathrm{M} 40 \mathrm{Y}\end{array}$} & \multicolumn{2}{|c|}{$\begin{array}{c}(8) \\
\text { PDA }\end{array}$} \\
\hline Alternaria alternata & & & & & 4 & & & & 44 & 36 & & & & & & \\
\hline Aspergillus flavus & & & & & & & & & & & & & & & 48 & 44 \\
\hline A. niger & 8 & 4 & & & & & & & & & & & & & 4 & \\
\hline A. tamarii & & & & & & & & & & & & & & & & 4 \\
\hline Fusarium moniliforme & & 4 & 4 & & & 4 & & & & & & & & & & \\
\hline F. solani & 32 & 52 & 16 & 4 & & & 12 & & & & & & & 4 & & \\
\hline Glomerella cingulata & & & & & & & & & & 4 & & & & & & \\
\hline Macrophoma sp. & 32 & 16 & 20 & 68 & 20 & 36 & & 4 & 28 & 36 & & & & & 28 & 16 \\
\hline Nigrospora sphaerica & & & & & & & & & & & & & & & 12 & 8 \\
\hline Penicillium citrinum & & & 20 & & & & 52 & 60 & 4 & 16 & & 4 & & & 28 & 16 \\
\hline Rhizoctonia sp. & 32 & 4 & 56 & 16 & 20 & 8 & & & 60 & 60 & & & & & 36 & 72 \\
\hline Other fungi & & 8 & & & & & 8 & 20 & & 12 & & 4 & & & & \\
\hline Non-infected kernels & 20 & 20 & 4 & 16 & 56 & 56 & 32 & 16 & 0 & 4 & 100 & 92 & 100 & 96 & 0 & 0 \\
\hline
\end{tabular}

* = Sphaeropsis sp.

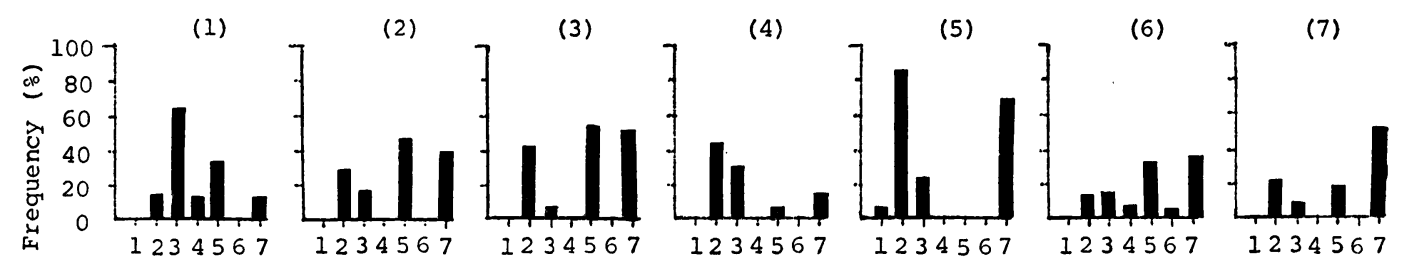
1. Alternaria alternat
2. Aspergillus niger
3. Fusarium moniliforme
4. Fusarium solani
5. Macrophoma sp. 6. Penicillium citrinum 7. Rhizoctonia sp.

Fig. 1. Isolation frequency of predominant fungi in the shells.

and Rhizoctonia sp. were predominantly isolated from both the kernels and the shells. Although A. niger and $F$. moniliforme were also isolated rather frequently, they were little isolated from the kernels. The relation between shell- and kernelinfection may be confirmed by future investigations.

\section{References}

1) Subrahmanyan, P., Rao, A.S.: Curr. Sci. (India), 43, 707 (1974).

2) Saito, M., Tanaka, K., McDonald, D., Mehan, V.K., Tsuruta, O., Manabe, M. and Matsuura, S.: Proc. Jpn. Assoc. Mycotoxicol., 20, 7 (1984). 